\title{
Preface: The Story behind the Story
}

My Villa Clara experience started in 2001, when my mother and I embarked on a tour, the Circuito Histórico de las Colonias Judías del Centro de Entre Ríos, ${ }^{1}$ a recent addition to Argentine cultural tourism. The tour would take us to northeastern Argentina, a six-hour journey by bus from the capital city of Buenos Aires, where my mother resided and I was born. We would be displacing ourselves geographically, of course; but even more important, we would also travel back in time, toward our shared past: the immigration of my mother's and my father's parents from Eastern Europe to the province of Entre Ríos. My grandparents had settled in the region at the end of the nineteenth century, making my parents the first generation born in rural Argentina and part of the memorialized "Jewish gauchos" of the colonias (rural settlements of immigrants). We had been warned that the tour might take longer than anticipated, and it did: there were sites that we could not reach due to heavy rainfall just before our arrival and others that we could only get to after taking long detours.

Although I was prepared for those traveling contingencies, I only now realize that I was totally unprepared for the emotional impact of the tour on my mother. Though we were both conscious of the passage of time, my mother remained incredulous that so little remained there of so much that she remembered. As we neared her grandparents' house in San Gregorio, my mother became very talkative, reminiscing about the chestnuts surrounding the property that, she assured us, would help us identify it easily. As we drew near, we saw no chestnuts or other distinguishing signals that would lead us to believe that anybody had ever lived there. The same scene repeated itself as we drove past the home of her parents-in-law. A neighbor who had stayed in the area pointed to a huge tree under which my paternal grandparents' house, he thought, had probably stood. Only memories remained of the experience of the Jewish Colonization Association, the organization that had helped these immigrants flee the Europe of their birth: there seemed to be few material traces of the homes they had first inhabited. Here is what my mother wrote about our trip:

I enjoyed visiting the places in San Gregorio where my father, my uncles, and my grandparents lived. My heart jumped often. I did not wish to say anything, but I saw all of them. I saw the beds with several mattresses piled up and the small ladder they made for us to get up there, since we were small. Grandfather with his beard that made us itch, grandmother with her clean handkerchief and her gray dress. Always so loving. They were zeide and bobe, ${ }^{2}$ not Salomón and Ana. I remember them well. I saw them. To get to their home we had to go through about 100 meters, I figure, covered by trees-nut 


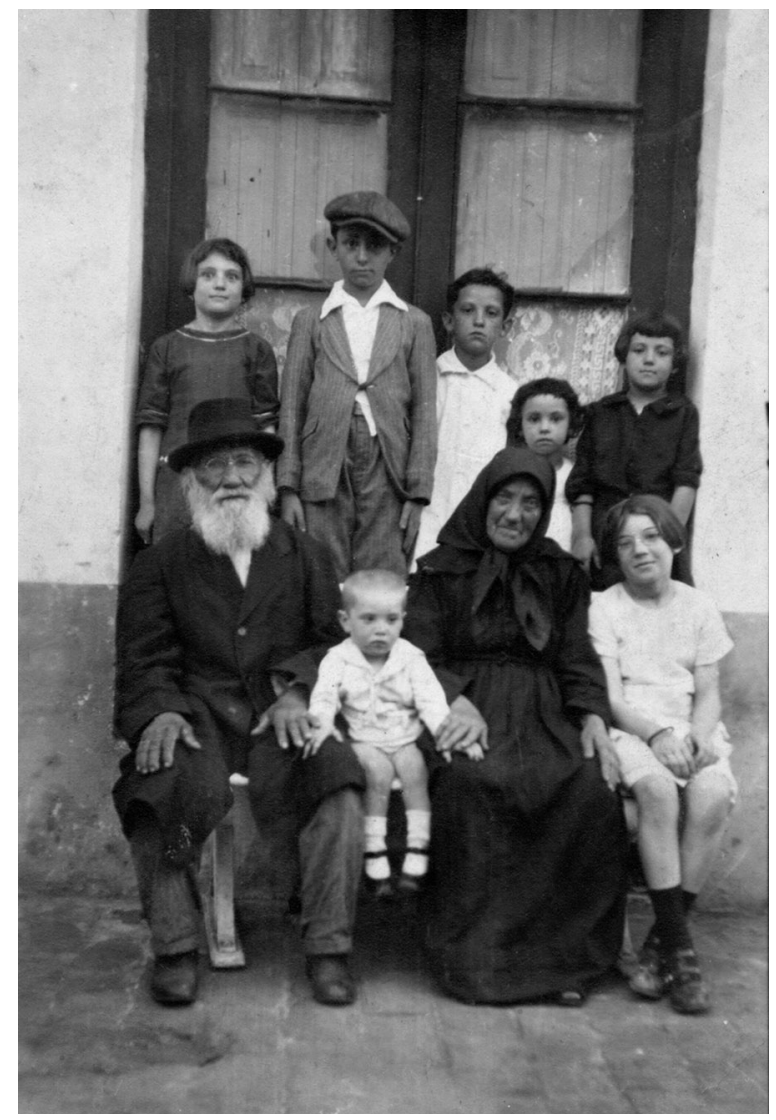

The family of Sara Furrer.

trees, almond trees, olive trees, plum trees, peach trees. We were very happy spending our summers there. My uncle, their oldest son, lived very close. $\mathrm{He}$ was an excellent musician, he played violin, viola, mandolin, and he taught his children ... My uncle Nissim lived in another colonia, Las Moscas ... Do you notice my poor handwriting? It's because I am touched by remembering all of them. And other things, like the breakfast, and the afternoon tea with traditional Russian pastries. The peones [rural employees] told my grandfather: Zeide, mir un gusien arbetein? [Shall we go to work, grandfather?]. My father left and moved to the city, Concordia, because he wanted to adelantar [go forward, progress] as they would say then...

When we arrived in Villa Clara we heard more stories about the displacement of the Jewish gauchos from the area, but we also heard about the histories of immigration of other Europeans and regional migrations of criollos (children 
of European parents born in Argentina). Such cultural variety in the human tapestry of such a small locality made me eager to return and undertake fieldwork to unearth its rich past while sharing daily life. When my mother and I returned early the next year as Villa Clara was organizing for the celebration of its centennial, I rented space from the Alvarez family, descendants of Swiss and Spanish immigrants, and moved in during a sabbatical semester in 2002. Their kindness made me feel at home sooner than expected, and sharing the excitement of fieldwork with students kept me grounded. Later I would become so involved in the reopening of the village museum that I decided to write a book about the material, oral, and written heritage of Villa Clara through public consultation and to donate its proceeds to contribute to the museum's activities.

Memorias de Villa Clara, written in Spanish for general audiences and published in 2005, did not quell the curiosity of some Clarenses (residents of Villa Clara). Some (particularly older descendants of the initial Jewish founders, a kind of intelligentsia that kept the initial history of the village alive) kept asking about "the other book," the one I had told them about when I first made the village my temporary home. I had spoken about my interest in understanding the village as a case study of the impact of nineteenth-century European immigrations on the construction of Argentine national identity and about my plan to weave together written sources and oral memories through dialogic discourse. The present book returns to my original intention: immersing myself in the daily life of the locality to account for the historical development of the village within the larger contexts of region and nation. A case study, based on a small sample, illuminates both the history and social organization of the larger society; and, conversely, the local events are better understood within the context of larger units of analysis (region, nation, transatlantic countries of origin).

History becomes enlivened through the ethnographic present. While an official national history disseminates a written version of the immigrant past-unless or until contested - through schools, museums, historical societies, tourist plans, and commemorative events, another history is latent and spreads in the course of daily interaction in localities. The national ideology favoring European immigration to Argentina might be unknown or forgotten at the local level, but the arrival of the first immigrants in the province or their influence on the social history of the village might be vividly remembered. Because this latent history based on memory and disseminated orally is rarely written or accounted for in private documents, it is less likely to survive. The interface between the written and the oral repositories of memories and the implications of remembering and forgetting for understanding the influence of the nineteenth-century European immigrants' saga on the construction of Argentine national identity provides the context for writing the social history of Villa Clara.

The term criollo is extremely complex and has a multiplicity of meanings. In 
Argentina, the term has three different meanings that change according to social context and historical period. The original meaning dates from the conquest of America, when the children of Spanish conquistadors born in the Virreinato del Río de la Plata, where the future Argentina would emerge, were called criollos. This use was prevalent during the colonial period, although there was a marked difference among the social statuses accorded individuals depending on whether both parents were born in Spain, born in America, or preceded the Spaniards (Amerindians). Eventually, this meaning was extended to anybody born in Argentina, as opposed to Europe, and social status was accorded by social class rather than by country of birth. The term gradually took a connotation of "rural dweller" and, although new terms did not appear to distinguish criollos by degree of ethnic mix, or mestizaje with indigenous populations or dislocated Africans, the term implied low socioeconomic status. When massive waves of European immigrants arrived in the Río de la Plata countries of Argentina and Uruguay at the end of the nineteenth century and early twentieth century and a sense of national identity became more pronounced, the term evolved to mean anybody who was native to the country and could claim citizenship.

Currently, criollo is the generalized term employed to mean anybody who is "from the country" in the Rioplatense region, often in marked contrast to "foreigner." There is an unstated understanding, however, that the social gradient that separates a wealthy from a poor criollo will be respected and acknowledged.

Chapter 1 traces the ideology of the new Argentine nation and its policies favoring the entry of European immigrants. As a metaphor for Argentine history, Villa Clara provides a way of reading the past as a succession of liberal and nationalist ideological periods.

Chapter 2 illustrates the implementation of immigrant policy at the provincial level. It traces the immigration of Europeans to Argentina and their settlement in Entre Ríos from 1850 (when the first cohort of Western Europeans arrived) to 1892 (when the last sizable influx, this time of Eastern Europeans, took place).

Chapter 3 focuses on the village's immediate surroundings. It narrates the saga of the Eastern Europeans' arrival and their daily life in an agricultural settlement closest to contemporary Villa Clara: Colonia Clara, founded in 1892 by the Jewish Colonization Association.

Chapter 4 begins with the opening of the railroad station in 1902 and the official founding of Villa Clara that attracted many of the new Jewish gauchos of the area. The people I talked to painted daily life vividly, alluding to sacrifices as they transported hard-won harvests to the railroad station through mud streets and as they organized themselves institutionally.

The nationalization of the British-owned railroad in 1947 spurred a halt in the economic advancement of the village, by then a regional development 
center, that triggered important demographic changes through regional population displacements and increasing urbanization. Chapter 5 traces the impact of such changes, as immigrants' descendants transformed into ethnic groups. The themes in the interviews depicted daily life centering at this time around internal rather than transatlantic migrations, as the rural areas became economically unsustainable. Low-income housing projects were built to accommodate the incoming criollos, many previously hired by immigrant farmers. As many Jewish gauchos living in the village or its hinterland moved to large cities (primarily Buenos Aires), many descendants of other immigrant cohorts (mainly from Western Europe) moved out of the rural areas and arrived in Villa Clara. For the first time in its history, Villa Clara experienced unemployment and poverty.

Chapter 6 begins with the closing of railroad passenger services in 1994. It epitomizes what people perceived as the end of an era when, as they put it, "there was work for everyone." Villa Clara became transformed from a producer of goods and services to a producer of heritage: the history of the immigrant cohorts residing in the village became reduced to their ancestors' arrival and settlement sagas, re-created in public performances that reified myths of origin. Furthermore, as ethnic diversity increased with the arrival of new populations, the voices claiming to tell the history of the village increased and clamored for attention in the space of a museum, a centennial celebration, and a project in cultural tourism. And yet the "official" version of the village's history-the one chosen for public presentation to the outside world and thus passed on through the educational system and disseminated by the writers of history-is often at odds with the versions told by people whose identities are framed by citizenship, ethnicity, and social class.

This case study advocates using the ethnographic method to elicit plural versions of local history and thus contributes to the understanding of a more inclusive and diverse social history. This approach, which can be replicated in a variety of situations, is particularly persuasive when the voice of immigrants is deemed relevant to tell national history. Immigration speaks to global connections: we should resist the provincialism of narrowing immigrant life to a particular place at a particular time. Villa Clara's case study may be used to open up research that connects immigration, memory, history, ethnography, heritage, and culture and to understand the political economy of memory and forgetfulness. 
THIS PAGE INTENTIONALLY LEFT BLANK 